\title{
Pengaruh Inovasi Produk dan Harga Terhadap Keputusan Pembelian Sepeda Motor Honda Supra X 125
}

\author{
Riza Fakhri Lupiko ${ }^{1, *}$ \& Handojo Djoko Waloejo ${ }^{2}$ \\ ${ }^{1,2}$ Departemen Administrasi Bisnis, Fakultas Ilmu Sosial dan Ilmu Politik, Universitas Diponegoro \\ *E-mail: rizafakhrilupiko@yahoo.com
}

\begin{abstract}
The means of transportation in the present day is an important need for human. To support human mobility today which is high, an efficient and adequate means of transportation is needed. In addition, it can accommodate daily activities. In particular, this study discusses the purchase of Honda Supra X $125 \mathrm{CW}$ Astra Motor Siliwangi motorcycle. The purpose of this study was to determine the effect of product and price innovation on the purchase decision of Honda Supra X $125 \mathrm{CW}$ motorcycle. This type of research uses quantitative methods with research type eksplanatory research, with data collection techniques through questionnaires. The population in this research are buyers and users of Honda Supra X $125 \mathrm{CW}$ Astra Motor Siliwangi with the number of samples taken is 95 respondents by Slovin method. Sampling using purposive sampling technique. Analytical methods used are validity test, reliability test, classical assumption test, correlation test, determination test, simple linear regression, multiple linear regression, $t$ test, and $F$ test. In this research is assisted by computer program to process data that is SPSS. Based on the results of the study note that partially, product innovation and price have a strong relationship strong enough to the purchase decision. This is indicated by the results of multiple correlation coefficient test of 0.490 . Significantly, the variables of product innovation and price have a positive effect indicated by the value of $F$ arithmetic bigger than F table that is equal to 15,291>3,952. Suggestions that can be given are PT. Astra Honda Motor should make changes to the body of Honda Supra X 125 motorcycle to look fresh and keep up with the times. Also consider the price to be more affordable or at the same price with the addition of features and technology on the Honda Supra X 125.
\end{abstract}

\begin{abstract}
Abstraksi Sarana transportasi pada jaman sekarang merupakan suatu kebutuhan yang penting bagi manusia. Untuk mendukung mobilitas manusia zaman sekarang yang tinggi maka diperlukan sarana transportasi yang efisien dan memadai. Secara khusus penelitian ini membahas mengenai pembelian sepeda motor Honda Supra X 125 CW Astra Motor Siliwangi. Tujuan penelitian ini adalah untuk mengetahui pengaruh inovasi produk dan harga terhadap keputusan pembelian sepeda motor Honda Supra X $125 \mathrm{CW}$. Tipe penelitian ini menggunakan metode kuantitatif dengan jenis penelitian eksplanatory research, dengan teknik pengumpulan data melalui kuesioner. Populasi yang terdapat dalam penelitian ini yaitu pembeli dan pengguna Honda Supra X 125 CW Astra Motor Siliwangi dengan jumlah sampel yang diambil adalah 95 responden dengan metode Slovin. Pengambilan sampel menggunakan teknik purposive sampling. Metode analissi yang digunakan adalah uji validitas, uji reliabilitas, uji asumsi klasik, uji korelasi, uji determinasi, regresi linear sederhana, regresi linear berganda, uji t, dan uji F. Dalam penelitian ini dibantu oleh program komputer untuk mengolah data yaitu SPSS.Berdasarkan hasil penelitian diketahui bahwa secara parsial, inovasi produk dan harga mempunyai keeratan hubungan yang cukup kuat terhadap keputusan pembelian. Hal ini ditunjukan dengan hasil uji koefisien korelasi berganda sebesar 0,490. Secara signifikan, variabel inovasi produk dan harga berpengaruh positif ditunjukan dengan nilai $\mathrm{F}$ hitung lebih besar dari $\mathrm{F}$ tabel yaitu sebesar 15,291 > 3,952. Saran yang dapat diberikan yaitu PT. Astra Honda Motor sebaiknya melakukan perubahan pada body sepeda motor Honda Supra X 125 agar terlihat fresh dan mengikuti perkembangan jaman. Selain itu mempertimbangkan soal harga agar lebih terjangkau atau dengan harga yang sama dengan penambahan fitur dan teknologi pada Honda Supra X 125.
\end{abstract}

Keywords: Marketing; Price; Product Innovation; Purchase Decision

\section{Pendahuluan}

Sarana transportasi pada jaman sekarang merupakan suatu kebutuhan yang penting bagi manusia. Hal tersebut disebabkan karena jaman yang semakin maju dan meningkatnya taraf hidup dan kebutuhan dari masyarakat. Selain itu adanya persaingan ketat yang memaksa untuk manusia berjuang agar tetap bertahan hidup. Kebutuhan sekunder pada zaman sekarang berkembang menjadi kebutuhan primer. Kebutuhan primer yang kita kenal dahulu mungkin hanya sandang 
(pakaian), pangan (makan) dan papan (tempat tinggal) sedangkan kebutuhan sekunder yang berperan sebagai penunjang dalam kehidupan sehari-hari antara lain sarana dan prasarana pendidikan, sarana dan prasarana kesehatan, alat komunikasi, dan alat transportasi. Untuk mendukung mobilitas manusia zaman sekarang yang tinggi maka di perlukan sarana transportasi yang efisien dan memadai. Pada jaman yang modern ini seringkali dihubungkan dengan gaya hidup yang mengikuti trend atau perkembangan jaman. Dengan keadaan tersebut, keputusan memilih suatu produk juga berperan dalam gaya hidup modern, sehingga keinginan untuk membeli produk yang bermerek turut mewarnai pola konsumsi seseorang (Hadi, 2007) menambahkan "secara individual maupun secara organisasi dorongan untuk melakukan pembelian bisa timbul karena memang ada kebutuhan".Tetapi ukuran sesuatu disebut sebagai "kebutuhan" tidak semata-mata dari pandangan ekonomi. Kebutuhan prestige, kebanggan dan simbol bonafiditas tidak bisa diletakan dalam lingkungan kehidupan konsumen maupun percaturan bisnis. Biasanya merek yang sudah sukses atau mapan dijadikan simbol sebagai produk yang sukses, sehingga ekuitas merek turut bepengaruh terhadap kondisi emosional konsumen itu sendiri. Meskipun terdapat banyak produk-produk pesaing yang sejenis, semuanya tergantung dari ekuitas konsumen terhadap merek tersebut. Jika konsumen sudah memahami benar tentang merek yang diyakininya, maka kepribadian merek dibenak konsumen akan semakin kuat. Ekuitas merek merupakan persepsi total konsumen terhadap merek yang dapat dibentuk melalui informasi baik dari pendapat teman atau pengalaman pribadi. Jika konsumen memilik persepsi yang baik terhadap merek akan mempengaruhi terbentuknya pilihan produk yang akan dibeli, selanjutnya akan membentuk sikap positif yang dapat mempengaruhi keputusan pembelian. Untuk menghasilkan produk yang marketable dan profitable secara berkelanjutan, maka perusahaan harus memperhatikan pentingnya inovasi produk.

Produk yang begitu-begitu saja akan dipandang konsumen sebagai produk yang membosankan dan mengalami kejenuhan, oleh karena itu kreativitas, modifikasi, dan inovasi sangat dibutuhkan untuk pengembangan produk tersebut tetap mendapatkan tempat di hati konsumen. Selain faktor tersebut, faktor harga juga mengambil peran penting dalam pemasaran. Strategi penentuan tinggi rendahnya harga sangat berpengaruh pada laku atau tidaknya suatu produk di pasar. Harga yang rendah atau terjangkau menjadi pemicu untuk meningkatkan kinerja pemasaran. Namun harga juga dapat menjadi indikator kualitas, dimana suatu produk dengan kualitas tinggi akan berani dipatok dengan harga yang tinggi pula. Harga juga dapat mempengaruhi konsumen dalam mengambil keputusan untuk melakukan pembelian suatu produk. Harga merupakan salah satu bauran pemasaran yang dapat digunakan perusahaan untuk mencapai tujuan pemasarannya (Swastha dan Irawan, 2000).

Akan tetapi dengan maraknya motor matic dengan kapasitas dan teknologi mesin yang sama dengan Honda Supra X 125 berdampak pada penjualan akhir-akhir ini. Orang mulai melirik varian matic dengan asumsi tidak capek dengan tidak perlunya memindahkan gigi persneling pada motor dan dengan kapasitas dan tekonologi mesin yang sama tidak takut untuk tertinggal dengan motor bebek pada umumnya. Sehingga menyebabkan penurunan penjualan pada Honda Supra X 125.

Berdasarkan uraian di atas, dapat diangkat menjadi suatu pembahasan dalam penelitian ini dengan judul "Pengaruh Inovasi Produk dan Harga Terhadap Keputusan Pembelian Sepeda Motor Honda Supra X 125 (Studi Kasus Pada Pembelian Sepeda Motor Honda Supra X 125 CW Astra Motor Siliwangi)“.

Perumusan masalah: (1) Apakah ada pengaruh inovasi produk terhadap keputusan pembelian pada produk sepeda motor Honda Supra X 125 CW?; (2) Apakah ada pengaruh harga suatu produk terhadap keputusan pembelian pada produk sepeda motor Honda Supra X 125 CW?; (3) Apakah ada pengaruh antara inovasi produk dan harga secara bersamaan terhadap keputusan pembelian 
pada produk sepeda motor Honda Supra X $125 \mathrm{CW}$.

Tujuan penelitian ini adalah sebagai berikut: (1) Untuk mengetahui pengaruh inovasi produk terhadap keputusan pembelian pada produk sepeda motor Honda Supra X $125 \mathrm{CW}$; (2) Untuk mengetahui pengaruh harga suatu produk terhadap keputusan pembelian pada produk sepeda motor Honda Supra X 125 CW; (3) Untuk mengetahui pengaruh secara bersamaan antara inovasi produk dan harga suatu produk terhadap keputusan pembelian pada produk sepeda motor Honda Supra X 125 CW.

\section{Kajian Teori}

Keputusan pembelian adalah pembentukan preferensi atas merek-merek dalam kumpulan pilihan yang kemudian berlanjut pada niat untuk melakukan pembelian pada suatu produk. Juga dapat didefinisikan sebagai tahap dalam proses pengambilan keputusan pembelian dimana konsumen benar-benar membeli produk tersebut (Kotler \& Amstrong, 2004). Menurut Kotler (2005) perilaku konsumen dipengaruhi oleh empat faktor yaitu (budaya, sub-budaya, dan kelas social), social (kelompok acuan, keluarga, serta peran dan status), pribadi (usia, tahap siklus hidup, pekerjaan, keadaan ekonomi, gaya hidup, kepribadian, dan kosep diri) dan psikologis (motivasi, persepsi, pembelajaran, keyakinan, dan sikap). Pemasar harus melihat lebih jauh bermacam-macam faktor yang mempengaruhi para pembeli dan mengembangkan mengenai cara konsumen melakukan pembelian. Selain itu juga harus dapat mengidentifikasi orang yang membuat keputusan pembelian, jenis keputusan pembelian, dan langkah-langkah dalam proses pembelian.

Inovasi adalah produk atau jasa yang dipersepsikan oleh kosnumen sebagai produk atau jasa baru. Inovasi dapat dikatakan sebagai terobosan yang berkaitan dengan produk-produk baru. Tetapi Kotler (2003) menambahkan bahwa inovasi tidak hanya terbatas pada pengembangan produk-produk atau jasa-jasa baru. Namun inovasi juga termasuk dalam pemikiran bisnis baru dan proses baru. Inovasi dipandang sebagai mekanisme perushaan untuk beradaptasi pada lingkungan yang dinamis. Oleh sebab itu maka perusahaan diharapkan untuk menciptakan pemikiran-pemikiran baru, ideide baru yang menawarkan produk inovatif serta memberikan pelayanan yang memuaskan bagi konsumen.Inovasi memiliki arti yang penting bukan hanya untuk mempertahankan kelangsungan hidup suatu perusahaan melainkan unggul dalam suatu persaingan.

Harga adalah jumlah uang (ditambah beberapa barang kalau memungkinkan) yang dibutuhkan untuk mendapatkan sejumlah kombinasi dari barang beserta pelayanannya (Swastha, 2002). Definisi lain harga adalah atribut produk atau jasa yang paling sering digunakan oleh sebagian besar konsumen untuk mengevaluasi produk. Harga merupakan suatu cara bagi seorang penjual untuk membedakan penawarannya dari para pesaing, sehingga besar konsumen untuk mengevaluasi produk. Harga merupakan suatu cara bagi seorang penjual untuk membedakan penawarannya dari para pesaing, sehingga penetapan harga dapat dipertimbangkan sebagai bagian dari fungsi diferensiasi barang dalam pemasaran. Penetapan harga suatu barang bagi manajemen merupakan salah satu keputusan sangat penting karena harga yang ditetapkan dapat menutupi semua ongkos atau bahkan lebih dari itu yaitu untuk mendapatkan laba.

\section{Metode}

Pada dasarnya metode penelitian merupakan cara ilmiah untuk mendapatkan data dengan tujuan dan kegunaan tertentu (Sugiyono, 2012). Metode penelitian bisnis dapat diartikan sebagai cara ilmiah untuk mendapatkan data yang valid dengan tujuan dapat ditemukan, dikembangkan, dan dibuktikan, suatu pengetahuan tertentu sehingga pada gilirannya dapat digunakan untuk memahami, memecahkan, dan mengantisipasi masalah dalam bidang bisnis. Metode penelitian ini dimaksudkan untuk memberi penjelasan tentang prosedur 
penelitian yang harus dilakukan oleh penulis dalam penyusunan penelitian.

Populasi adalah wilayah generalisasi yang terdiri atas: obyek/ subyek yang mempunyai kualitas dan karakteristik tertentu yang ditetapkan oleh peneliti untuk dipelajari dan kemudian ditarik kesimpulannya (Sugiyono, 2004). Penelitian ini menggunakan metode kuantitatif dengan jenis penelitian eksplanatory, yaitu menguji rumusan hipotesis penelitian untuk menjelaskan ada atau tidaknya pengaruh antar variabel dependen dan variabel independen melalui pengujian hipotesis yang telah dirumuskan. Populasi dalam penelitian ini adalah para pembeli secara cash dan kredit. Pengguna Honda Supra X $125 \mathrm{CW}$ dalam rentang waktu 2012 - 2017 di Astra Motor Siliwangi sejumlah 1.632 orang. Sampel adalah bagian dari jumlah dan karakteristik yang dimiliki oleh populasi tersebut.

Bila populasi besar, dan peneliti tidak mungkin mempelajari semua yang ada pada populasi, maka peneliti dapat menggunakan sampel yang diambil dari populasi itu (Sugiono, 2012). Sampel yang diambil harus berkenan menjadi responden dan dapat memberikan jawaban dari pertanyaan yang diajukan dalam kuesioner. Jumlah sampel yang digunakan dalam penelitian ini merupakan hasil dari perhitungan dengan menggunakan rumus Slovin.

\section{Hasil dan Pembahasan}

Pada bagian ini akan dipaparkan pembahasan mengenai hasil analisis yang telah dilakukan tentang pengaruh Inovasi Produk dan Harga terhadap Keputusan Pembeian pada sepeda motor Honda Supra X 125.

Inovasi Produk mempunyai pengaruh signifikan terhadap keputusan pembelian sepeda motor Honda Supra X 125. Hal ini dapat dilihat dari hasil uji koefisien determinasi yaitu sebesar $19,2 \%$ artinya bahwa variabel keputusan pembelian dapat dijelaskan oleh variabel Inovasi sebesar 19,2\%. Kemudian ditinjau dari hasil uji signifikansi yang menunjukkan bahwa nilai $t_{\text {hitung }}=4,832$ lebih besar dari $t_{\text {tabel }}=1,662$. Dengan demikian dapat disimpulkan bahwa ada pengaruh signifikan antara Inovasi terhadap Keputusan Pembelian sepeda Motor Honda Supra X 125. Hasil penelitian ini sesuai dengan penelitian Akhiri (2016) yang menyatakan bahwa terdapat pengaruh yang signifikan inovasi produk terhadap keputusan pembelian.

Harga mempunyai pengaruh signifikan terhadap keputusan pembelian sepeda motor Honda Supra X 125. Hal ini dapat dilihat dari hasil uji koefisien determinasi yaitu sebesar $17,6 \%$ artinya bahwa variabel keputusan pembelian dapat dijelaskan oleh variabel harga sebesar 17,6\%. kemudian ditinjau dari hasil uji signifikansi yang menunjukkan bahwa nilai $t_{\text {hitung }}$ sebesar 4,582 lebih besar dari nilai $t_{\text {tabel }}$ sebesar 1,662. Dengan demikian dapat disimpulkan bahwa ada pengaruh signifikan antara variabel Harga terhadap keputusan pembelian.Hasil penelitian ini sesuai dengan penelitian Amrullah (2016) yang menyatakan bahwa harga berpengaruh signifikan secara positif terhadap keputusan pembelian.

Ada pengaruh signifikan antara Inovasi dan Harga terhadap keputusan pembelian sepeda motor Honda Supra X 125. Hal ini dapat dilihat dari hasil uji koefisien determinasi yaitu sebesar 24\%. Kemudian ditinjau dari hasil uji signifikansi yang menunjukkan bahwa $F_{\text {hitung }}$ sebesar 45,089 lebih besar dari nilai $F_{\text {tabel }}$ sebesar 3,952 atau $\mathrm{F}_{\text {hitung }}=43,015>\mathrm{F}_{\text {tabel }}=3,952$. Dengan demikian dapat disimpulkan bahwa ada pengaruh signifikan antara variabel Inovasi dan Harga terhadap Keputusan Pembelian pada Sepeda Motor Honda Supra X 125.

\section{Kesimpulan}

Berdasarkan hasil penelitian mengenai pengaruh inovasi produk dan harga terhadap keputusan pembelian Honda Supra X 125 pada Astra Motor Siliwangi Kota Semarang maka dapat ditarik beberapa kesimpulan.

Inovasi Produk. Inovasi produk yang dimiliki oleh Honda Supra X 125 termasuk 
dalam kategori baik dengan nilai rata-rata yaitu sebesar 4,08. Hal ini dibuktikan dengan penilaian responden mengenai Honda Supra X 125 sudah cukup inovatif untuk menghadapi persaingan pasarsepeda motor kelas bebek dan memberikan manfaat yang sesuai dengan kebutuhan dan dapat membanggakanpara penggunanya. Menurut responden, adanya lini produk yang baru pada Honda Supra X 125 termasuk dalam kategori cukup mampu menyaingi kompetitornya dalam persaingan pasar sepeda motor. Hal ini ditunjukan dengan nilai rata-rata sebesar 3,92 pada rekapitulasi jawaban responden untuk variabel inovasi produk. Perbaikan produk yang telah ada atau penambahan inovasi kualitas Honda Supra X 125 juga dinilai cukup baik oleh konsumen dengan ditunjukan angka yang masih dibawah rata-rata pada rekapitulasi jawaban responden untuk variabel inovasi produk sebesar 3,93. Responden menyatakan perlunya PT Astra Honda Motor (AHM) untuk melakukan pengembangan produk khususnya pada Honda Supra X 125 untuk menaikan penjualan. Ditunjukan dengan angka rata-rata sebesar 4,00 meskipun termasuk dibawah rata-rata dari rekapitulasi jawaban responden sebesar 4,08. Inovasi produk berpengaruh terhadap keputusan pembelian sepeda motor Honda Supra X 125 dengan nilai koefisien regresi sebesar 0,465 dengan tingkat signifikasi 0,05 . Sehingga semakin inovatif Sepeda Motor Honda Supra X 125 maka semakin tinggi tingkat keputusan pembelian pada Sepeda Motor Honda Supra X 125.

Harga. Harga yang dimiliki oleh Honda Supra X 125 termasuk dalam kategori baik dengan nilai rata-rata yaitu sebesar 3,96. Hal ini dibuktikan dengan penelitian responden mengenai Honda Supra X 125 sudah cukup terjangkau dan dapat bersaing terhadap kompetitor lainnya pada pasar sepeda motor bebek. Beberapa konsumen menyatakan bahwa Honda Supra X 125 cukup sesuai antara harga dengan kualitas yang didapatkan ketika membeli produk. Meskipun dengan nilai yang masih di bawah rata-rata rekapitulasi jawaban responden untuk variabel harga yaitu sebesar 3,83 . Harga pada Honda Supra X 125 menurut responden cukup bersaing dengan produk di kelasnya yaitu kelas sepeda motor bebek dengan angka yang dihasilkan pada rekapitulasi jawaban responden untuk variabel harga yaitu sebesar 3,94. Menurut repsonden, dalam proses pengambilan keputusan pembelian pada Honda Supra X 125 termasuk cukup berpengaruh dengan angka sebesar 3,86 yang termasuk dibawah rata-rata pada rekapitulasi jawaban responden untuk variabel harga. Harga berpengaruh terhadap keputusan pembelian sepeda motor Honda Supra X 125 dengan nilai koefisien regresi sebesar 0,500 dengan tingkat signifikasi 0,05 . Sehingga semakin terjangkau Sepeda Motor Honda Supra X 125 maka semakin tinggi tingkat keputusan pembelian pada Sepeda Motor Honda Supra X 125.

Keputusan Pembelian. Keputusan pembelian yang dimiliki oleh Honda Supra X 125 termasuk dalam kategori baik dengan nilai rata-rata yaitu sebesar 3,74 . Hal ini dibuktikan dengan penelitian responden mengenai Honda Supra X 125 mengenai kesesuaian antara keputusan pembelian dengan tujuan dalam membeli suatu produk, kemantapan membeli produk melalui pemikiran yang matang, merekomendasikan produk kepada orang lain serta melakukan pembelian ulang pada Honda Supra X 125. Menurut responden, cukup diperlukan adanya pemrosesan informasi dari berbagai sumber sebelum membeli produk Honda Supra X 125. Hal ini dibuktikan dengan angka yang dihasilkan pada rekapitulasi jawaban responden untuk variabel keputusan pembelian sebesar 3,56. Pada saat konsumen melakukan pembelian Honda Supra X 125, responden menyatakan bahwa sudah sesuai dengan kebiasaan dalam membeli produk lainnya. Ditunjukan dengan angka sebesar 3,71 pada rekapitulasi jawaban responden untuk variabel keputusan pembelian. Responden penelitian menyatakan cukup merekomendasikan kepada rekan atau kerabat terdekat mereka untuk melakukan pembelian pada Honda Supra X 125 dengan ditunjukan angka sebesar 3,74 pada rekapitulasi jawaban responden untuk variabel keputusan pembelian. Dengan angka dibawah rata-rata yaitu sebesar 3,61 pada rekapitulasi jawaban responden untuk variabel keputusan pembelian. Responden menyatakan cukup berminat untuk 
melakukan pembelian ulang setelah membeli dan memakai produk Honda Supra X 125.

Inovasi Produk dan Harga. Berpengaruh terhadap keputusan pembelian Sepeda Motor Honda Supra X 125 dengan nilai koefisien regresi dari Inovasi Produk sebesar 0,317 dan nilai koefisien regresi dari Harga sebesar 3,08. Sehingga semakin inovatif sepeda motor Honda Supra X 125, semakin terjangkau juga produk sepeda motor Honda Supra X 125 maka semakin tinggi tingkat keputusan pembelian sepeda motor Honda Supra X 125.

\section{Saran}

Berdasarkan hasil penelitian dan pembahasan mengenai pengaruh inovasi produk dan harga terhadap keputusan pembelian produk sepeda motor Honda Supra X 125 pada dealer Honda Astra Motor Siliwangi dapat penulis berikan beberapa saran.

Berdasarkan variabel inovasi produk, sebaiknya PT AHM melakukan perubahan pada body Supra X 125 agar lebih fresh dan mengikuti style, hal ini mempengaruhi konsumen ketika melihat pertama kali bahwa body dari Supra X 125 terkesan kaku dan tidak stylish. Dengan body yang cukup stylish dipadukan dengan stiker dan fitur masa kini maka diharapkan calon pembeli yang memiliki jiwa muda dan bergairah cukup tertarik untuk membeli sepeda motor Honda Supra X 125.

Berdasarkan variabel Harga, dibanding dengan kompetitornya masih dirasa cukup mahal bagi beberapa konsumen. Mereka beranggapan bahwa dapat mendapatkan fitur yang lebih dengan harga yang lebih terjangkau. Apalagi sekarang sepeda motor matik sudah mulai dilirik konsumen karena lebih ergonomis dan tidak capek mengoper gigi. Atau bisa dengan penambahan fitur dengan syarat harga yang ditawarkan tetap sama dan masuk akal bagi para konsumen untuk membeli sepeda motor Honda Supra X 125.
Berdasarkan variabel keputusan pembelian, seharusnya perusahaan dapat memberikan informasi dan iklan yang lebih menarik dan informatif mengenai sepeda motor Honda Supra X 125. Apalagi di era globalisasi ini peran media sosial juga sangat berpengaruh terhadap publikasi suatu produk. Konsumen perlu diyakinkan agar dapat memilih suatu kendaraan dan dalam hal ini perusahaan perlu menyakinkan konsumen bahwa mereka tidak salah memilih untuk membeli sepeda motor Honda Supra X 125.

\section{Daftar Referensi}

Ferdinand, Augusty. (2006). Metode Penelitian Manajemen: Pedoman Penelitian untuk Penulisan Skripsi \& Disertasi Ilmu Manajemen. Semarang: Badan Penerbit Universitas Diponegoro.

Ileya, Ida Nur. (2008). Pengaruh Inovasi Produk, Citra Merek dan Harga terhadap Keputusan Pembelian Tablet Ipad Merk Apple. Skripsi. Universitas Diponegoro.

Kotler, Philip. (2005). Manajemen Pemasaran. Jilid 1 Edisi Ke sebelas. Jakarta: Prentince Hall.

Kotler, Philip dan Gary Amstrong. (2006). Prinsip-prinsip Pemasaran. Edisi $\mathrm{Ke}$ duabelas. Jakarta: Prenhalindo.

Kotler, Philip. (2003). Manajemen Pemasaran. Jakarta: Perihalindo.

Kotler, Philip. (2000). Marketing Management. The Millenium Edition. New Jersey: Prentice Hall, Inc.

Pearce, dan Richard Robinson. (2008). Manajemen Strategis. Edisi 10. Jakarta: Salemba Empat.

Sugiyono. (2006). Metode Penelitian Bisnis. Cetakan ke sembilan. Bandung: CV Alfabeta.

Sugiyono. (2008). Metode Penelitian Bisnis. Bandung: Alfabeta. 
Sugiyono. (2010). Metode Penelitian Bisnis. Cetakan ke limabelas. Bandung: CV Alfabeta.

Swastha, Basu \& Irawan. (1998). Manajemen Pemasaran Modern. Yogyakarta: Liberty.

Swastha, Basu DH. (2002). Manajemen Pemasaran. Yogyakarta: Liberty.

Swastha, Basu dan Irawan. (2005). Manajemen Pemasaran Modern. Yogyakarta: Liberty.

Swasta, Basu dan Irawan. (2010). Manajemen Pemasaran Modern. Edisi Keempat. Yogyakarta: Liberty.
Web:

Mortech blogspot. 2014. Diakses dari http://blog.mortech.co.id/generasihonda-supra-x-125/

Prasetyo676.com. 2015. Diakses dari http://prasetyo676.com/2015/01/12/data -aisi-penjualan-sepeda-motor-tahun2014-honda-semakin-dominankawasaki-dan-tvs-naik/

PT Astra International Tbk - Honda, 2017. Diakses dari https://www.astra.co.id/AboutAstra/Astra-Organization-Structure

Astra Honda Motor, 2017. Diakses dari http://www.astra-honda.com/price-list. 